\title{
A study on the impact of workplace environment on employee's performance: with reference to the Brandix Intimate Apparel - Awissawella
}

Lankeshwara P

Department of Management and Finance, Faculty of Management, Social Sciences and Humanities, General Sir John Kotelawala Defence University, Sri Lanka

\begin{abstract}
In the current era of highly volatile business environment, organizations are facing emerging $\square$ challenges in achieving operational excellence with the intention to offer a competitive advantage and secure lasting results for their customers. The most crucial factor that affects the organization performance is its employee since human resources are considered as a source of sustainable competitive advantage. The workplace environment gives an immense impact to the employees either towards the negative outcomes or positive outcomes. The objective of this study was to identify the impact of workplace environment on the employee's performance. The study has utilized primary data and a sample of size 85 has chosen in accordance the Morgan approach of sample selection including both managerial and non-managerial employees from Brandix Intimate Apparel- Awissawella through the proportionate sampling technique, using already developed questionnaire. Multiple Regression Model has been utilized as the main data analyzing technique. The survey results revealed that the job aids, supervisory support and physical work environment as positively influential for the employee's performance and job aid as the most critical predictor. Implications of the findings and recommendations are offered.
\end{abstract}

KEYWORDS: Employee's Performance, Job Aids, Supervisor Support, Physical Work Environment

Corresponding author: P. Lankeshwara, Email: nishu.prabha@gmail.com 


\section{INTRODUCTION}

Achieving operational excellence is increasingly becoming a key area of focus in the apparel industry. Any of the apparels try to continuously engage in activities that could improve productivity and service to a true excellent level. When concerning about the Brandix Intimate Apparel, it also tries to achieve the operational excellence with the intention to offer a competitive advantage and secure lasting results for their customers. For this purpose number of insights was drawn to identify how their branches performed their activities and whether they achieved the expected productivity. Finally it has identified that increasing efficiency and effectiveness in the process is one of the key development areas. So this clearly implies that Brandix Intimate Apparel largely concerns about the performance of their employees since the expected productivity of the organization mainly depend on the performance of the employees.

Factors of workplace environment play an important role towards the employee's performance. By having a proper workplace environment, it helps in reducing the number of absenteeism and thus can increase the employees' performance which will lead to the increasing number of productivity at the workplace. Therefore, it is so important to find what factors of workplace environment causes for the employee's performance.

According to the above evidence, objective of this study was to identify the impact of workplace environment on the employee's performance.

\section{LITERATURE REVIEW}

\subsection{Employees' Performance}

Employee's performance is depending on the willingness and also the openness of the employees itself on doing their job. By having this willingness and openness of the employees in doing their job, it could automatically increase the employees' productivity which also leads to the performance (Sinha, 2001).

According to the previous studies, there are different points of view regarding the employee's performance. Some scholars have argued the job performance as a result of behavior. Moto wildo \& Scotter (1994) stated that performance is based on behaviors or activities that are associated with the goals of an organization. Moreover, job performance is the action or behavior itself and not the result of actions or a consequence. Anzi (2009) suggested that the organizations can improve job performance through controlling employees' behaviors. According to the Borman \& Motowidlo (1997), there are two types of employees' behavior that could leads to the employees' performance as task performance and contextual performance.

Stup (2003) illustrated that employers have to get the employees task to be done on track to achieve organization goal or target and standard performance. By having such a procedure employers could be able to monitor their employees and help them to improve their performance. Moreover, in order to motivate the employees to perform their task well, employers should implement a reward system based on the performance of the employees. And also on-thejob coaching, performance appraisals, counseling session, interviews and also the performance improvement plans can be used to improve the employees' performance (Stark \& Flaherty, 1999).

Employees' performance is the most important dependent variable in an industrial and organizational psychology. There are several factors which influence for the employees' performance. Among those, factors of workplace environment play an important role towards the employees' performance. Normally, employees' performance level is depending on the quality of the employees' workplace environment which are the job aid, 
supervisor support and also the physical workplace environment. These three factors determine how the employees' get engaged or attached to the organization (Chandrasekar, 2001).

\subsection{Job Aids and Employees' Performance}

Job aids are performance support tools which are used on the job and step-by-step descriptions of how to do a task. The purpose of a job aid is to guide and facilitate performance and as well as to support the work activity (Saklani \& Jha, 2011). According to Pipe (1986), job aid is being used by the employees as to support them in term of giving direction or procedure.

As a performance support tool, job aids cause to enhance the performance in three ways as external support, extrinsic support and intrinsic support. External support means that the employees need to take leave from work and look for the source as for their reference to their job. The second way is through the extrinsic support. An extrinsic support means that the job aid is being given within the system itself. The final way is called the intrinsic support. An intrinsic support is an insider or software that is being used as for the efficiency of workflow (Cavanaugh, 2004).

\subsection{Supervisor Support and Employees Performance}

Supervisors in any organization play a vital role in affecting employees' attitude and behavior. They are the first line managers who have the responsibilities of leading the subordinates in their group task and the groups in the organizations (Elangovan \& Karakowsky, 1999). Many scholars suggested that there is a positive relationship between the support form supervisor and the beneficial outcome such as, job commitment, employee retention and moreover performance.
According to the Gagnon \& Michael (2004), when the employees have supportive relationship with their immediate supervisor it tends to committed to higher performance and satisfaction. Many authors suggested that employee perceived support form supervisor make the employee more satisfied and performance oriented in the organization. Several studies about supervisor's role in training programs based on a sample of 45 trainees in UK organizations (Axtell et al., 1997), and 100 technical employees in North Kuching City Hall, Malaysia generally showed that properly implemented supervisor's role in training programs had increased job performance in the workplace.

Moreover, Nijman (2004) illustrated that when there is a very good communication skill especially during the training program, the employees will probably increase their competency and job performance.

\subsection{Physical Work Environment and Employees Performance}

A physical work environment can result a person to fit or misfit to the environment of the workplace and it is also known as an ergonomic workplace. There are some factors of physical work environment which help employees to perform their job more effectively and which leads to enhance their job satisfaction, such as lightings, the floor configuration, office layout and also the furniture layout (Brill et al, 1985).

According to the Vischer (2007), physical work environment is one of the most important factor which influences on work performance. Evidence accumulated that the physical work environment in which people work affects both job performance and job satisfaction. McCoy \& Evans (2005) explained that if employees dissatisfy with their working environment and once the employees become stressors at the work place, the employees tend to do their work very slowly. This will directly affects for the employees performance and as well as for the overall productivity of the organization. 
According to the Vischer (2007), employees affect by the environment of the place they are working and by having a good environment, the employees could apply their energy and their full attention to perform work.

\section{RESEARCH METHODOLOGY}

\subsection{Conceptual Framework}

The following figure indicates the conceptual frame work of the research.

\begin{tabular}{|l|l|}
\hline $\begin{array}{l}\text { Independent } \\
\text { variables } \\
\text { Factors of workplace } \\
\text { environment } \\
\text { - Job Aids } \\
\text { - Supervisor } \\
\quad \begin{array}{l}\text { Support } \\
\text { Physical } \\
\text { Environment }\end{array}\end{array} \mid \begin{array}{l}\text { Dependent } \\
\text { Variable } \\
\text { Employee's } \\
\text { Performance }\end{array}$ \\
\hline
\end{tabular}

Figure 1. Conceptual Framework

Source: Researcher's own conceptualization, 2015

\subsection{Data Collection}

In the present study, both Primary and Secondary data was utilized. The main data collection has done using an already developed questionnaire, designed to collect the data from employees by using likert scale as strongly agree, agree, neutral, disagree and strongly disagree. Secondary data was collected from company documents, articles and through the internet.

\subsection{Population and Sample}

The study area was Awissawella branch of Brandix Intimate Apparel and there were 114 staff members. Sample of size 85 has chosen in accordance the Morgan approach of sample selection including both managerial and nonmanagerial employees through the proportionate sampling technique.

\subsection{Data Analysis}

The Correlation and Regression Analysis have been conducted to identify the relationship between work place environment and performance of employees. Before conducting the Correlation Analysis, Cronbach's alpha test has done in order to understand whether the multiple likert questions in the questionnaire are reliable.

\section{RESULTS AND DISCUSSION}

\subsection{Data Presentation}

\subsubsection{Employee's Performance and} Demographic Profile

\section{Employee's Performance by Age}

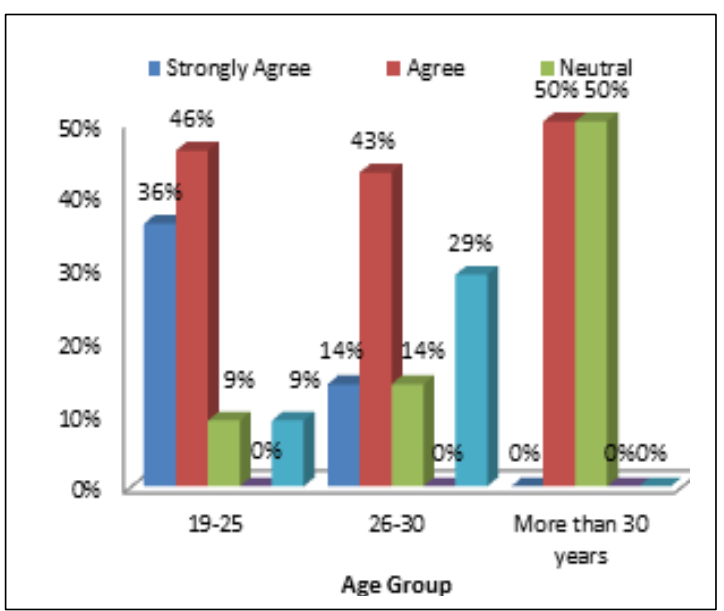

Figure 2. Employee's Performance by Age

Source: Survey Data, 2015 
In the view of age of the employees, it was very important demographic factor regarding the performance of employees.

According to the figure 2, within the age group 19-25 and 26-30 majority of the employee had positive attitudes regarding their performance level. Within the age group more than 30 years, half of the employees agreed with their performance level and the rest had neutral attitudes toward their performance level.

\section{Employee's Performance by Marital Status}

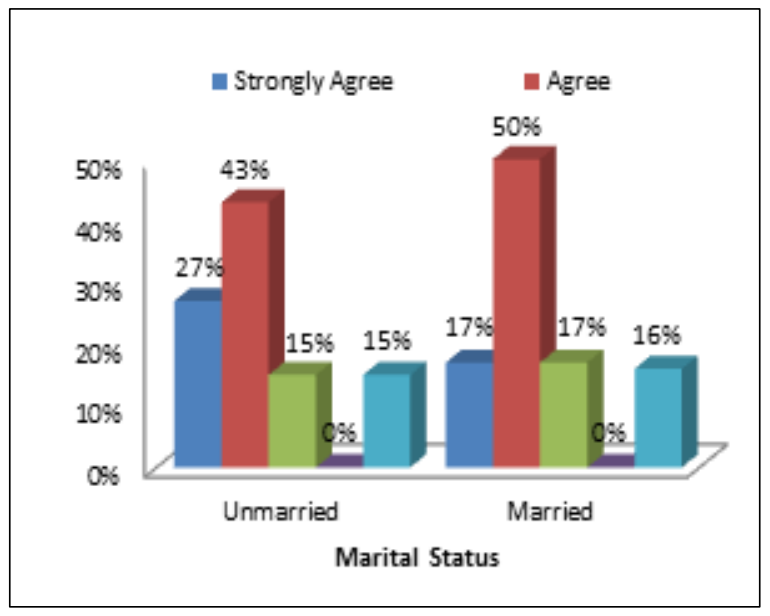

Figure 3. Employee's Performance by Marital Status

Source: Survey Data, 2015

According to the figure 3 , it illustrates performance of employees according to the marital status. There was no highly considerable difference between attitudinal concerns on performance level of married and unmarried employees.

Majority of the unmarried employees (70\%) and married employees (67\%) have recorded positive attitudes regarding their performance level while less than $1 / 4$ of the unmarried and married employees have neutral and negative attitudes towards their performance level.

\section{Employee's Performance by Ethnicity}

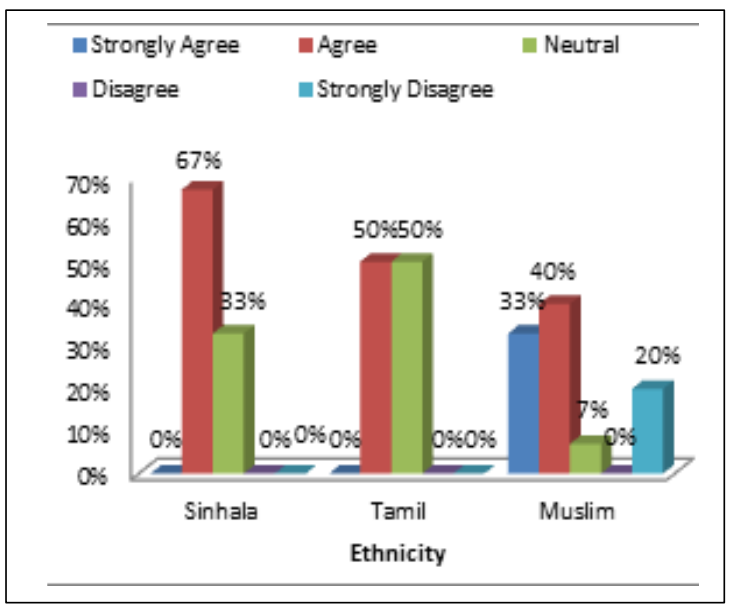

Figure 4. Employee's Performance by Ethnicity

Source: Survey Data, 2015

Figure 4 shows the employee's performance according to the ethnicity. Referring to the figure, more than half or $67 \%$ of the Sinhala employees were satisfied with their performance level and Tamil employees were equally in neutral and agree level.

When considering the Muslim employees, figure shows that majority $(73 \%)$ have positive attitudes and also $20 \%$ were in strongly disagree level regarding their performance.

\subsubsection{Employee's Performance and Socio Economic Profile}

\section{Employee's Performance by Education Level}

Figure 5 explains the performance of employees according to their education level.

According to the figure, the education levels $\mathrm{A} / \mathrm{L}$ category and diploma category, the majority (56\% and $78 \%$ ) were in satisfied levels and the most important thing is the employees who are qualified higher education level are totally satisfied with their performance level. 


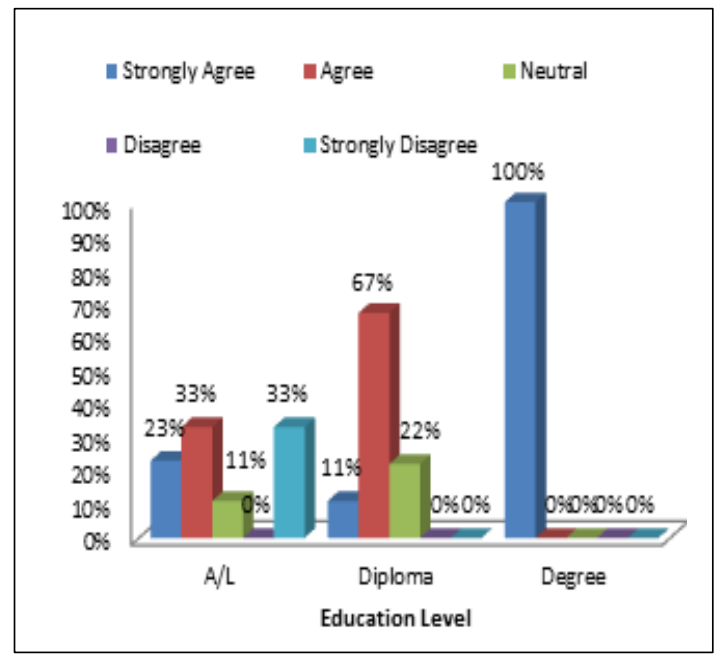

Figure 5. Employee's Performance by Education Level

Source: Survey Data, 2015

Employee's Performance by Period of Service

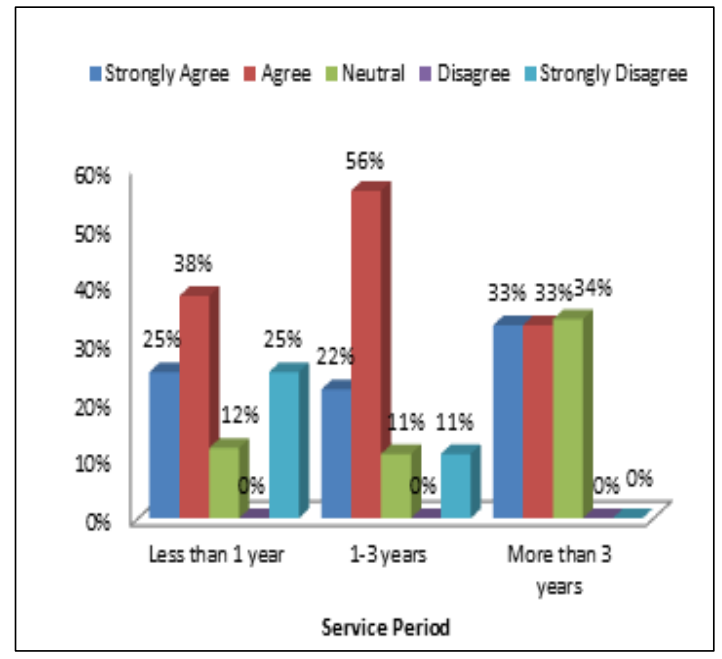

Figure 6. Employee's Performance by Service Period

Source: Survey Data, 2015

According to the figure 6, it illustrates majority of the employees whose service period is less than one year and 1- 3 year had positive attitudes towards their performance level and there was no highly considerable difference among strongly agree, agree and neutral level of attitudinal concern on performance of employees whose service period is more than 3 years.

Overview of the Level of Perception on Job Aids

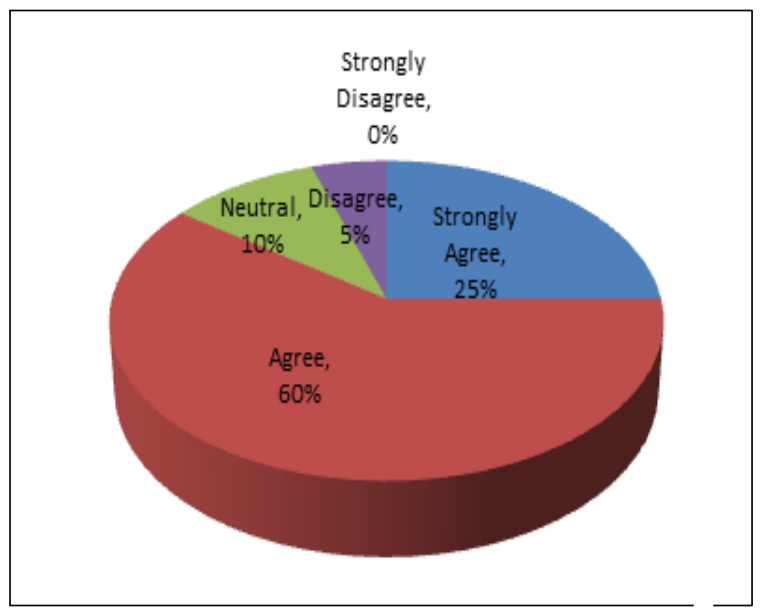

Figure 7. Overview of the Level of Perception on Job Aids

Source: Survey Data, 2015

Figure 7 shows the employee's attitudinal concerns on their job aids provided by the organization. Majority of the employees (85\%) were at the satisfactory level about their current job aids level. Only $10 \%$ of the employees have recorded neutral attitudes and very small portion $(5 \%)$ had dissatisfied perception on the job aids.

\section{Overview of the Level of Perception on Supervisor Support}

According to figure 8, it explains the employee's attitudinal concern on supervisor support. Majority of the employees $(70 \%)$ have recorded positive attitudes and $30 \%$ of the employees had neutral attitudes regarding their supervisors support. Further, no one was disagreed the attitudinal concern on supervisor support. 


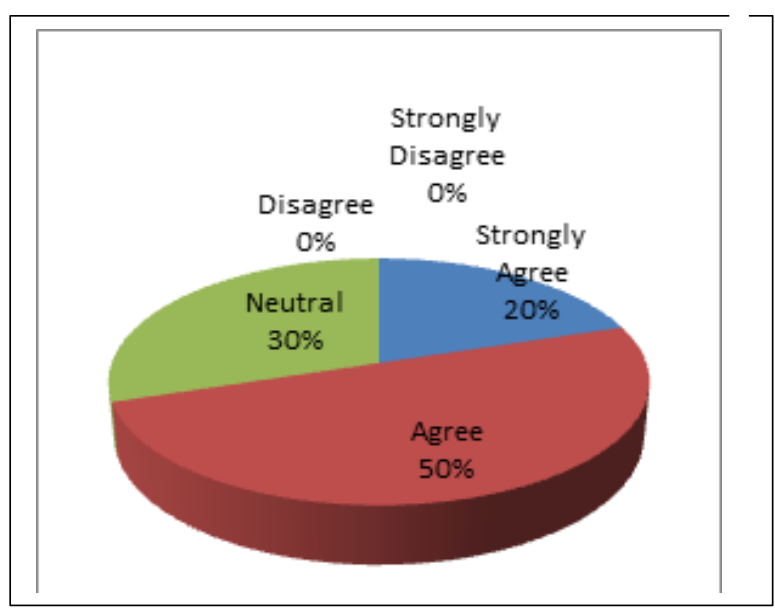

Figure 8. Overview of the Level of Perception on Supervisor Support

Source: Survey Data, 2015

Overview of the Level of Perception on Physical Work Environment

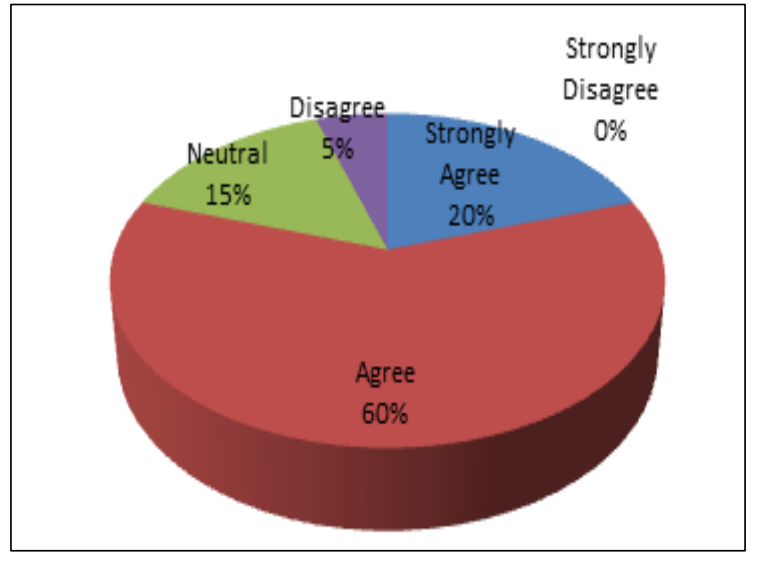

Figure 9. Overview of the Level of Perception on Physical Work Environment

Source: Survey Data, 2015

Figure 9 explains the employee's attitudinal concern on physical work environment.

According to the figure, higher portion of the employees $(80 \%)$ satisfy with their physical working environment.
In contrast, very small portion of the employees (5\%) have recorded negative attitudes regarding their physical working environment and $15 \%$ of the employees were at neutral level.

Overview of the Level of Perception on Employee's Performance

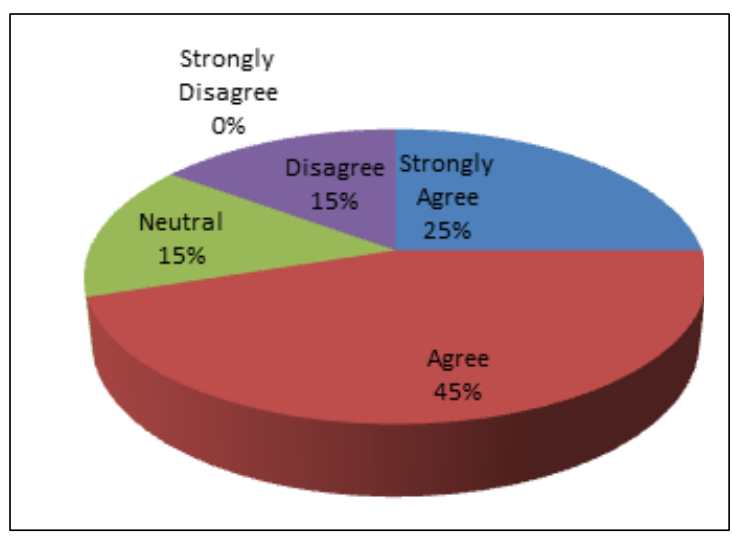

Figure 10. Overview of the Level of Perception on Employee's Performance

Source: Survey Data, 2015

Figure 10 illustrates the level of the employee's performance. Majority of the employees (70\%) were at the satisfactory levels about their current job performance level. Only small portion (15\%) had dissatisfied perceptions on their job performance level.

According to the overall picture, it is possible to conclude that employee's performance level of Brandix Intimate Apparel- Awissawella was at satisfactory level.

\subsection{Data Analysis}

\subsubsection{Reliability Test (Cronbach's Alpha)}

Within this study, in order to measure the job aids, supervisor support, physical work environment and performance of employees, several questions were applied and each question had 5 scales from strongly disagree to strongly agree. 


\section{Results of the Reliability Test}

Table 1: Reliability Statistics

\begin{tabular}{lll}
\hline Dimension & $\begin{array}{l}\text { Cronbach's } \\
\text { Alpha }\end{array}$ & $\begin{array}{l}\text { Number } \\
\text { of item }\end{array}$
\end{tabular}

\begin{tabular}{lll}
\hline Job Aids & 0.953 & 3 \\
Supervisor & 0.919 & 4 \\
Support & 0.885 & 3 \\
Physical Work & 0.924 & 2
\end{tabular}

Environment

Performance Of

Employees

Source: Survey Data, 2015

According to the results of reliability statistics, Cronbach's Alpha value of each variable was greater than 0.7. Therefore, it is possible to conclude that all the questions were reliable to measure the explanatory variables (job aids, supervisor support and physical work environment) and the dependent variable (performance of employees).

\subsubsection{Pearson's Correlation Analysis}

With the intention of identifying the influential factors for the employee's performance and determining the nature and strength of the relationship between the explanatory variables and response variable Pearson's Correlation procedure has been utilized under this section.

Table 2: Results of the Correlation Analysis

\begin{tabular}{lll}
\hline Dimension & $\begin{array}{l}\text { Correlation } \\
\text { Coefficient }\end{array}$ & P-value \\
\hline Job Aids & 0.919 & 0.000 \\
Supervisor & 0.857 & 0.000 \\
Support & 0.882 & 0.000 \\
Physical Work & & \\
Environment & & \\
\hline
\end{tabular}

Source: Survey Data, 2015
According to the results of the Pearson's Correlation Analysis, job aids, supervisor support and physical work environment were significantly correlated with the performance of employees as the $\mathrm{P}$ values of those three variables were less than 0.05 significance level.

When concerning the correlation coefficient, all the three variables have recorded strong degree of positive correlation with the employee's performance.

\subsubsection{Regression Analysis}

\section{Model Summery}

Table 3: Results of the Model Summery

\begin{tabular}{lc} 
Figure & Value \\
& \\
\hline $\mathrm{R}$ & 0.946 \\
$\mathrm{R}^{2}$ & 0.895 \\
Adjusted R $^{2}$ & 0.875 \\
Standard Error of Estimation & 0.462
\end{tabular}

Source: Survey Data, 2015

R-square tells how much of the variation of the dependent variable is explained by the independent variables. According to the results, from the total variation of employee's performance $89.5 \%$ has explained by the job aids, supervisor support and physical work environment.

Then only $10.5 \%$ of variance of employee's performance has explained by other influencing factors, which were not covered by this study.

The adjusted $\mathrm{R}$ square explains extent to which the model is fit for the population. The adjusted $\mathrm{R}$ square of the study was 0.875 and it indicates that the higher portion of the model $(87.5 \%)$ is fit for the population. 


\section{Analysis of variance (ANOVA)}

Table 4: Results of the Analysis of Variance

\begin{tabular}{lllll}
\hline Model & SS & DF & F & Sig \\
\hline Regression & 29.130 & 3 & 45.427 & 0.000 \\
Residual & 3.420 & 16 & & \\
Total & 32.550 & 19 & & \\
\hline
\end{tabular}

Source: Survey Data, 2015

The above table 4 has revealed that 32.550 from total sum of squares, 29.130 can be explained by regression and 3.420 are explained by residual value. Hence, the model is statistically significant as relatively large portion of model is explained by regression. As per the above information $\mathrm{P}$ value is 0000 . Therefore, the statistical evidence of the model supports to reject the null hypothesis $(\mathrm{P}$ value $<0.05)$. It concludes that the overall fitted model can be applied significantly for predicting the performance of the employees.

\section{Summary of the Coefficient Table}

Table 5: Results of the Coefficient Table

\begin{tabular}{|c|c|c|c|c|c|}
\hline $\begin{array}{l}\text { Predict } \\
\text { or }\end{array}$ & $\begin{array}{l}\stackrel{0}{\mathscr{0}} \\
: \frac{0}{0} \\
0 \\
0\end{array}$ & 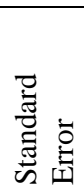 & $\stackrel{\pi}{0}$ & $H$ & $\dot{00}$ \\
\hline$\dot{U} \vec{a}$ & -3.375 & 0.616 & & -5.480 & 0.000 \\
\hline$\stackrel{0}{0}$ & 1.227 & 0.352 & 0.712 & 3.485 & 0.003 \\
\hline 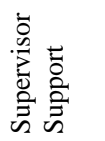 & 0.721 & 0.289 & 0.396 & 2.498 & 0.024 \\
\hline 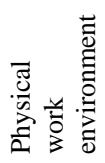 & -0.192 & 0.429 & -0.111 & -0.448 & 0.660 \\
\hline
\end{tabular}

Source: Survey Data, 2015
According to the coefficients table, job aids and supervisor support were significant as the $\mathrm{P}$ values of those two variables were less than 0.05 significance level.

Physical work environment has recorded as an insignificant explanatory variable with the employee's performance due to higher $\mathrm{P}$ value.

Based on the results of the above analysis, the equation of the regression can be depicted as follows.

$$
\begin{aligned}
& Y=-3.375+1.227 X_{1}+0.721 X_{2} \\
& \text { Where, } \\
& Y=\text { Performance of Employees } \\
& X_{1}=\text { Job Aids } \\
& X_{2}=\text { Supervisor Support }
\end{aligned}
$$

$\beta$ value represents the extent to which the value of the independent variable contributes to the variance of the dependent variable.

The constant have the unstandardized $\beta$ value as -3.375 . It indicates the value of the employee's performance, when all of the independent factors remain constant.

$\beta$ value of job aids suggests that, if job aids component is increased by one unit, employee's performance will increase by 1.227 units when all of other variables remain constant and as same as coefficient of the supervisor Support indicates, when it increase by one unit, employee's performance will also increase by 0.721 units.

Job aids have the highest $\beta$ value as 1.227 and it has become the most influential factor for the employee's performance. Further, all the explanatory variables which is in the regression equation positively influence for the performance of the employees. 


\section{CONCLUSION AND FURTHER WORK}

\subsection{Conclusions}

According to the findings of graphical representation, demographic factors such as age, marital status and ethnicity have shown considerable variation regarding the performance of employees. Under socio economic profile, education level and period of service and attitudinal concern on job aids, supervisor support and physical work environment have emerged as significant factors with employee's performance.

With the intention of determining the nature and strength of the relationship between the factors of work place environment and employee's performance, three explanatory variables have been studied and among those only supervisor support and job aids have shown significant influence for the employee's performance and physical work environment was insignificant with the employee's performance. Among all the demographic and socio economic factors, attitudinal concern on job aids has emerged as the most important factor for predicting the employee's performance and both job aids and supervisor support were positively influential for the performance of the employees.

\subsection{Further Works}

Job aids were the key determinant of employee's performance. Job aid helps in term of providing procedure for the employees towards their task and it is to guide and facilitate performance. Such workplace aids are readily available to help minimize error rates and employee dissatisfaction. Therefore, it is essential to facilitate required job aids for the employees.

Supervisor support was crucial for employee to complete the job. Supervisor's interpersonal role is important to encourage positive relation and increase self-confidence of the employee.
Hence, it should continue and improve the supervision towards the subordinates in order to create a significant relationship in between the supervisor and the employees.

Physical work environment is not significantly affecting the employees' performance. Hence the physical work environment at Brandix Intimate Apparel- Awissawella branch need to improve, because favorable work environment allow workers to perform better, improve productivity, maximize quality in their performance.

\section{REFERENCES}

AL-ANZI NM. Workplace environment and its impacts on employee's performance: A study submitted to Project Management Department in Saudi Aramco, Open University of Malaysia. 2009.

AXTELL CM, MAITLIS S \& YEARTA SK. Predicting immediate and longer-term transfer of training, Personnel Review. 1997;201:213.

BORMAN, WC, MOTOWIDLO, SJ. Task performance and contextual performance: The meaning for personnel selection research. Human Performance. 1997;99:109.

BRILL M, MARGULIS S \& KONAR E. Using office design to increase productivity. Buffalo, NY: Westinghouse. 1985.

CAVANAUGH TB. The new spectrum of support: Reclassifying human performance technology. Performance Improvement. 2004; 28:32.

CHANDRASEKAR K. Workplace environment and its impact on organisational performance in public sector organizations. International Journal of Enterprise Computing and Business System. 2001;1:20.

ELANGOVAN AR \& KARAKOWSKY L. The role of trainee and environmental factors in 
transfer of training: An exploratory framework. Leadership and Organization Development Journal. 1999; 268:275.

GAGNON MA \& MICHAEL JH. Outcomes of perceived supervisor support for wood production employees. Forest Products Journal. 2004; 172:177.

MCCOY JM \& EVANS GW. Physical work environment. Thousand Oaks, CA: Sage Publication. 2005; 219:245.

MOTOWIDLO SJ \& VAN SCOTTER JR. Evidence that task performance should be distinguished from contextual performance. Journal of Applied Psychology. 1994; 475:480.

NIJMAN DJJ. Differential effects of supervisor support on transfer of training. Enchede: University of Twente. 2004.

PIPE P. Introduction to Performance Technology, Washington, DC: National Society for Performance and Instruction. 1986; 129:144.

SAKLANI A \& JHA S. Impact of ergonomic changes on office employee productivity. International Journal of Management Research. 2011.

SINHA ES. The skills and career path of an effective project manager. International Journal of Project Management. 2001; 1:7.

STARK PB \& FLAHERTY J. The manager's pocket guide to leadership skill. Canada : HRD Press, Inc. 1999.

STUP R. Control the factors that influence employee success. Managing the Hispanic Workforce Conference. Cornell University and Penneylvania State University. 2003.

VISCHER JC. The effects of the physical environment on job performance: Towards a theoretical model of workspace stress. Stress and Health. 2007;175:184. 